\title{
An Experiment Using Two Methods of Teaching Accounting for Leases in Intermediate Accounting
}

\author{
Pamela Baker \\ Texas Woman's University
}

Intermediate Accounting students aged 23 to 37 were divided randomly into two treatment groups and one control group as part of a class exercise. Students completed pre- and post-quizzes testing their knowledge of lease accounting. Group One read the lease material before the class lecture and practice, and Group Two read the chapter after the same lecture and practice. The control group participated by only taking the quizzes. The results indicate that reading the chapter after lecture and practice yields better understanding and higher confidence in learning.

Keywords: Teaching Accounting, Accounting Education, Intermediate Accounting

\section{INTRODUCTION}

Studying accounting is difficult for many students, perhaps as hard as learning a new language (Buckhaults \& Fisher, 2011). This may be because, much like a musician playing the piano, accounting often requires both left-brain analytics and right-brain whole-picture thinking. Creating synapses that engage both sides of the brain requires more practice than many learning tasks, supporting research that strategies that use the whole brain are best when studying accounting (Lee \& Hung, 2009).

Intermediate Accounting likely is the most complex class that accounting majors face, to the point that it is recommended that they schedule more time for study and take fewer other classes when taking Intermediate Accounting (Carrington, 2010). The content of the class makes up the majority of the Financial Accounting and Reporting Section of the Uniform CPA Exam (Roger, 2019). Moreover, those hiring accounting majors often use the performance in this class as a key indicator of a student's abilities (Bernardi \& Bean, 2002). Increasing numbers of colleges and universities use the CPA Exam pass rate as an external measure of the success of their accounting programs (Morgan \& Ihrke, 2013). Therefore, finding ways to maximize a student's learning and retention of data is important to the student, the professor, the accounting program, and the college or university.

Today's millennial students arrive in the world with screens in front of their faces and rarely look away from them. They stand in the same room and text one another instead of talking to one another (Student Interviews, 2019). They enjoy a different pace and method of learning, are satisfied with Googling the answer to most questions, find reading less and less necessary, and prefer learning materials that are delivered to cater to their "visual, auditory, and even kinesthetic needs" (Laskaris, 2016). Some report never reading their college texts, and others indicate that they do not bother to purchase texts 
(Baker and Irving, 2019). While they do read, they are said to read with a specific purpose in mind and scan the material to avoid reading all of it (Tapscott, 2008).

Improving teaching and learning in Intermediate Accounting the focus of substantial research. Moreover, reading with comprehension is important both for learning accounting and to be able to teach oneself as a lifelong learner. This paper adds to the body of research on teaching strategies for Intermediate Accounting, reporting the results of a treatment-based approach testing two different methods of teaching lease accounting to millennial students randomly assigned to read the material before or after lecture and practice.

\section{LITERATURE REVIEW}

\section{Teaching Intermediate Accounting}

Because of the difficulty of Intermediate Accounting, a substantial body of research has been devoted to teaching methods that enhance student learning and performance in this class. For instance, Faelo (2016) finds that using real-world examples of earnings management help students better understand earnings management behavior. Amernic and Robb (2003) use quality of earnings as a unifying theme to help enhance student understanding. Case studies can be effective in helping Intermediate Accounting students develop higher-level skills such as analysis, judgment, and dealing with uncertainty (Boyce, 2001; Sawyer, 2000). Moreover, teaching Intermediate Accounting using a business activity model appears to improve student understanding (Catanach, Croll, \& Grinaker, 2000). Administering multiple take-home exams may help adult students learn the topics covered in Intermediate Accounting (Wilson, 2009). Lindquist and Olsen (2007) found that students report less frustration when provided with final, one-number homework check figures in an Intermediate Accounting class, allowing the students to gauge better whether or not they are on track. Scott (2017) reports that using unique cases for each student vastly reduced the amount of plagiarism and improved academic integrity. Sargent (2013) reports that students proficient in prerequisite skills earned better project and cumulative final exam scores in nonprerequisite areas, and grades in Intermediate II were also better compared to the two prior terms after adding a proficiency test. Plucinski (2010) describes that students with low GPAs benefit more from the addition of post-lecture quizzes, while students with higher GPAs benefit more from the addition of prelecture quizzes.

The grade the student intends to earn, math ability, and GPA have a strong association with student performance in an Intermediate Accounting class (Maksy, 2014). Rich and Dereshiwsky (2011) find that student performance in online accounting classes without proctored exams is similar to that of face-toface classes.

The suggestions put forth in these research studies do not necessarily reflect what happens in the classroom. Loebl (2014) surveyed instructors at public four-year colleges and universities in 10 states, finding that instructors rely heavily on traditional means of teaching Intermediate Accounting and not those emphasizing communications skills. Dow and Feldmann (1997) suggest that $70 \%$ or more of Intermediate Accounting course grades rely on examinations, and oral or written communication skills account for $10 \%$ or less of students' grades.

\section{How Millennials Learn}

Millennials prefer to learn using technology and discussing course content (McCleery, 2015). They prioritize work-life balance more than previous generations and expect it earlier in life (Smola \& Sutton, 2002). Most use websites such as Google and Wikipedia as their first-choice source when seeking answers (Nichols, 2008). The online classroom allows millennials to do course work when convenient (Meyer, 2017). According to Marston (2005), Millennials grew up in an era of great wealth and "feel entitled to life's rewards without paying their dues," making them less prepared put in the time to study than previous generations. Millennials prefer to learn through auditory and verbal methods (Papoulias, 2016). They find that reading a book from cover to cover is "not a good use of...time" and may not give reading their full attention (Tapscott, 2008). 


\section{METHODOLOGY}

As part of a class exercise, students were assigned randomly to two treatment groups and one control group. Of the original 71 potential participants, eight students were eliminated because of previous work or study experience related to accounting for leases. The 63 remaining students were given a pre-test to assess their knowledge of accounting for leases. The highest percentage earned was $15 \%$ on a multiplechoice quiz where guessing should yield 25\%. One-third of students (21) participated in one of two methods of teaching:

1) Reading the chapter first, listening to a lecture on leases, and practicing problems with guided in-class practice

2) Listening to the same lecture, practicing the same guided, in-class problems, but reading the chapter afterward.

The treatment is the timing of when the students read the chapter-before or after the lecture and practice. A third group served as the control group and participated only in the pre- and post-quizzes. All students took a post-quiz that included both knowledge questions in multiple-choice format and questions about their confidence in learning using a scale from one to five, with one being in what they had learned and five being very high confidence in learning. ANOVA was used to test the difference in pre-test and post-test average scores and t-tests to check for differences between each of the three groups using a $5 \%$ confidence level.

\section{Hypotheses}

H1: The first hypothesis asks if there is a difference in the increase in knowledge of accounting for leases from pre-quiz to post-quiz based on when students read the chapter. If there is a difference in student learning based on when the students read the chapter, there should be a statistically significant difference between scores on pre- and post-quizzes.

$\boldsymbol{H o}_{1}$ : There will be no difference between the increase in score from pre-quiz to post-quiz for Group 1 versus Group 2.

$\mathrm{Ha}_{1}$ : There will be a statistically significant difference in the increase in score from pre-quiz to post-quiz for Group 1 versus Group 2.

H2: The second hypothesis tests if students perceive a difference in their confidence in learning based on when they read the material. If there is a difference in confidence in learning based on when students read the chapter, there should be a statistically significant difference between the measure of confidence in learning between the pre-reading and post-reading groups.

$\mathrm{Ho}_{2}$ : There will be no statistically significant difference between the confidence in learning reported by Groups 1 and 2.

$\mathrm{Ha}_{2}$ : There will be a statistically significant difference between the confidence in learning reported by Groups 1 and 2.

\section{RESULTS}

\section{Hypothesis 1}

The average increase in scores from pre-quiz to post-quiz of the two treatment groups show a significant increase in average post-read quiz score over average pre-read quiz score. Results were tested for statistically significant differences between the three groups using ANOVA, and t-tests used to test for statistical differences between Groups 1 and 2. 
FIGURE 1

INCREASE IN SCORE FROM PRE-QUIZ TO POST-QUIZ

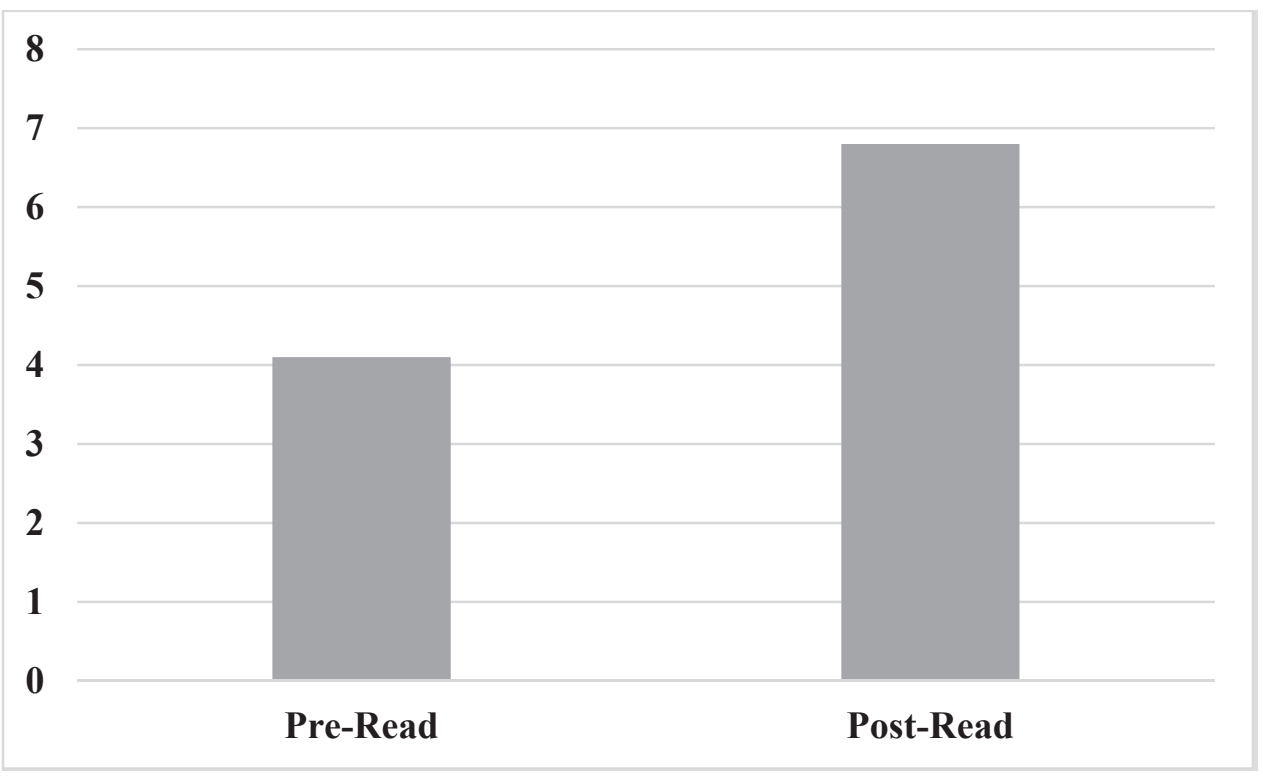

The t-tests show a statistically significant difference in the means between the control group and Group 1, as well as between the control group and Group $2(\mathrm{p}<.01)$. Both Group 1 and Group 2 show a statistically higher mean than the control group, suggesting that the students learned from the lecture and practice. There are significant differences between the quiz increases for Groups 1 and $2(\mathrm{p}<.001)$, suggesting that students better understand the material if they wait to read the chapter after listening to a lecture and practicing problems.

\section{Hypothesis 2}

Students report differences in confidence in what they have learned about leases. These results were tested for statistical significance using t-tests.

FIGURE 2

\section{CONFIDENCE IN LEARNING}

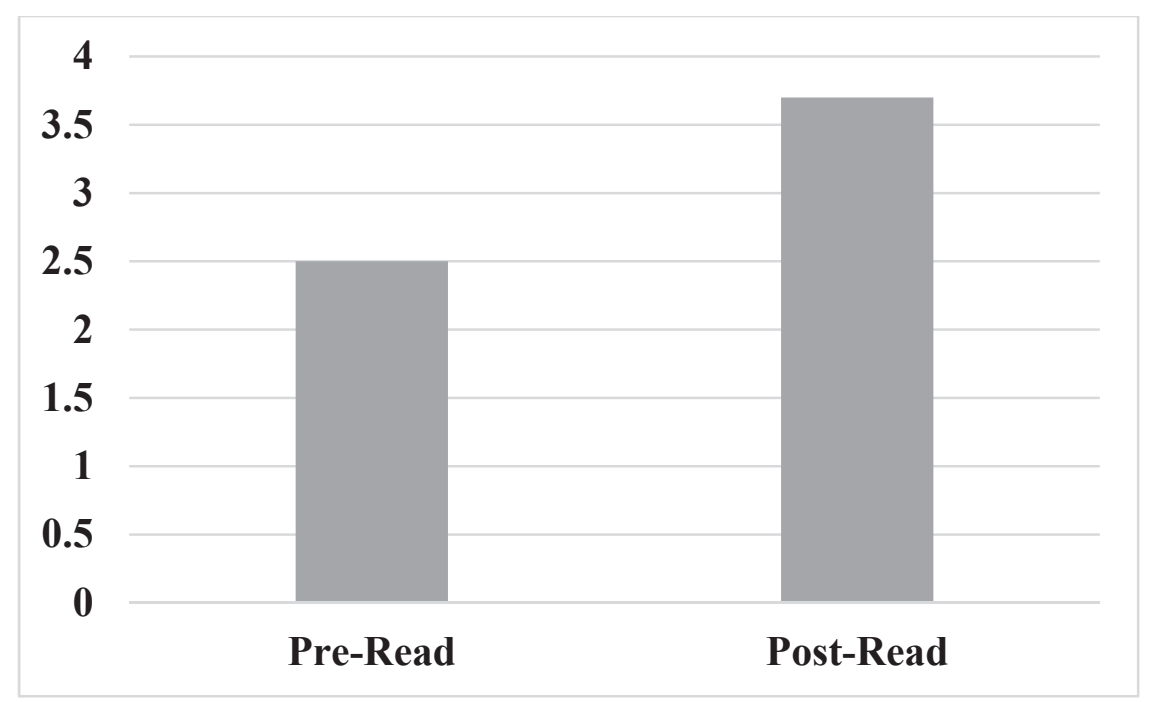


Students reported the highest confidence in learning when reading the chapter after lecture and practice. Individual t-tests show a statistically significant difference between the confidence in learning of Groups 1 and $2(\mathrm{p}<0001)$.

\section{DISCUSSION}

Overall, students who read the chapter after lecture and practice had a higher increase in score from pre-quiz and post-quiz and reported the highest confidence in learning. Reasons may include difficulty reading the chapter without an introduction to the material; a grounding in the material may allow the student to scan the reading, as they report preferring.

However, students may have poor reading comprehension skills. Students reported that the lecture and practice helped them read the chapter with much greater understanding and that they often find reading the chapter "cold" to be too difficult. The information is complex, and the lecture and practice helped them understand better what to look for as important, leading to greater understanding. This supports Etter and Ross' (2013) findings that students learning to summarize show improved comprehension and understanding and Tapscott's (2008) suggestion that millennials read by scanning, with a specific purpose in mind.

Seven students $(11 \%)$ commented on the importance of a face-to-face explanation in helping them learn. Some students reported that they rarely read the chapters, depending solely upon PowerPoint slides and in-class lectures and practice to learn the material. Many students $(15 \%)$ report difficulty in reading and suggest that the book is "too hard" for them to read effectively. Overall results suggest that an initial reading of the chapter without some pre-interpretation from the professor is more difficult than reading after the lecture and practice take place.

\section{LIMITATIONS AND SUGGESTIONS FOR FUTURE RESEARCH}

This study seeks to find ways to better present complex material to a generation that reads differently, demands ready answers, wants immediate responses, and spends less time concentrating. However, it uses a convenience sample and a limited number of students in one type of class in one discipline. Repetition and other studies aimed at short-block identification of material for students are needed to determine if this method is better for student learning. More work needs to be done to seek correlations between problems with reading comprehension and decrements of learning in accounting classes. 


\section{REFERENCES}

Amernic, J., \& Robb, S. (2003). Quality of earnings as a framing device and unifying theme in intermediate financial accounting. Issues in Accounting Education, 18(1).

Baker, P., \& Irving, L. (2019). The casual approach to reading: An examination of how millennials use their texts in college classes. Working paper submitted for publication Summer 2019.

Bernardi, R., \& Bean, D. (2002) The importance of performance in intermediate I on performance in subsequent accounting courses. Accounting Educators' Journal, 14(2).

Boyce, G. (2001). Fostering deep and elaborative learning and generic (soft) skill development: The strategic use of case studies in accounting education. Accounting Education, 10(1), 37-60.

Buckhaults, J., \& Fisher, D. (2011) Trends in accounting education: Decreasing accounting anxiety and promoting new methods. Journal of Education for Business, 86(1), 31-35,

Brink, A. (2010). The impact of pre- and post-lecture quizzes on performance in intermediate accounting II. Issues in Accounting Education, 28(3). Retrieved August 2013.

Catanach, A., Croll, D., \& Grinaker, R. (2000, November) Teaching intermediate financial accounting using a business activity model. Issues in Accounting Education, 15(4), 583-603.

Dow, K. J., \& Feldmann, D. A. (1997). Current approaches to teaching intermediate accounting. Issues in Accounting Education, (12), 61-75.

Etter, E., \& Ross, B. (2013) The use of article summaries in accounting courses: Improving students' reading comprehension, learning, thinking, and communication skills. American Journal of Business Education; Littleton, 6(6), 595.

Faella, J. (2016, October). Enhancing the learning experience in intermediate accounting Research in Accounting Regulation, 28(2), 123-127.

Laskaris, J. (2016). How to engage millennials: Five important moves. eLearning. Retrieved from https://www.efrontlearning.com/blog/2016/03/5-strategies-to-engage-the-millennials.html

Lee, L., \& Hung, J. (2009) Effects of using whole brain instruction on accounting learning. International Journal of Distance Learning Technologies, 7(3).

Lindquist, T., \& Olsen, L. (2007). How much help, is too much help? An experimental investigation of the use of check figures and completed solutions in teaching intermediate accounting. Journal of Accounting Education, 25(3).

Loebl, J. (2014) Learning from others how to teach intermediate accounting more effectively: A survey of instructors on course content, assessment and course management. Journal of Higher Education Theory and Practice, 14(1).

Maksy, M. (2014, October). Factors associated with student performance in intermediate accounting: A comparative study. Journal of Applied Business and Economics, 16(5).

McCleery, R. (2015). Teaching wildlife techniques to millennials using a flipped classroom. Wildlife Society Bulletin, 39(4), 822-826.

Meyer, S. (2017). How millennials learn best. Rapid Learning Institute. Retrieved from https://rapidlearninginstitute.com/blog/study-millennials-learn-best/

Morgan, J., \& Ihrke, F. (2013) For-profit higher education and CPA exams success rates: Comparing forprofit institutions with public (state) institutions and private not-for-profit institutions of higher education. Advances in Business Research, 4(1), 77-86.

Munter, P., \& Reckers, P (2010, May). Uncertainties and budget shortfalls hamper curriculum progress on IFRS. Issues in Accounting Education, 25(2), 189-198.

Nichols, A. (2008). Preferred learning methods of the millennial generation. Salve Regina University Research. Retrieved from https://digitalcommons.salve.edu/cgi/viewcontent.cgi?article=1017\&context=fac_staff_pub

Papoulias, L. (2016). Determining the dominant learning style of millennial students enrolled in online business courses to help instructors apply the appropriate teaching methodology in online courses. Pepperdine University. Dissertation Abstracts. 
Pelton, L. E., \& True, S. L. (2004). Teaching business ethics: Why gen y? Marketing Education Review, 14(3), 63-70.

Plucinski, K. (2010). Readability of intermediate accounting textbooks. Academy of Educational Leadership Journal; Arden, 14(2), 49-57.

Rich, A., \& Dereshiwsky, M. (2011, September) Assessing the comparative effectiveness of teaching undergraduate intermediate accounting in the online classroom. Journal of College Teaching and Learning, 8(9).

Roger (2013). What material to expect on the exam. Roger CPA Exam Review. Retrieved from https://www.rogercpareview.com/blog/what-material-expect-cpa-exam

Sargent, C. (2013, August) Find it, fix it, and thrive: The impact of insisting on proficiency in prerequisite knowledge in Intermediate Accounting. Issues in Accounting Education, 28(3).

Sawyer, A. J. (2000). Developing essential skills through case study scenarios. Journal of Accounting Education, 18(3), 257-82.

Scott, S. (2017). From plagiarism-plagued to plagiarism-proof: Using anonymized case assignments in intermediate accounting. Accounting Perspectives, 16(4).

Smola, K., \& Sutton, C. (2002). Generational differences: Revisiting generational work values for the new millennium. Journal of Organizational Behavior, 23, 363-382.

Student Interviews. (2019). Casual interviews of students about reading preferences. Part of Class Exercises in Intermediate Accounting Class. Texas Woman's University.

Tapscott, D. (2008). Grown up digital: How the next generation is changing your world. McGraw Hill, 2008.

Wilson, M. (2009). Effective strategies for teaching intermediate accounting to adult learners. Business Education Innovation Journal, 1(1), 4-9. 